\title{
THERMAL MODELING OF SEMI-TRANSPARENT PHOTOVOLTAICS: IMPACTS ON THE CELL EFFICIENCY AND ON THE ZONE PERFORMANCE
}

\section{MODELAGEM TÉRMICA DE FOTOVOLTAICOS SEMITRANSPARENTES: IMPACTOS NA EFICIEENCIA DA CÉLULA E NO DESEMPENHO DA ZONA}

\author{
Thiago Toledo Viana Rodrigues ${ }^{1}$ \\ Universidade Federal de Viçosa, Viçosa, MG, Brasil, thiago.t.rodrigues@ufv.br \\ Joyce Correna Carlo ${ }^{2}$ \\ Universidade Federal de Viçosa, Viçosa, MG, Brasil, joycecarlo@ufv.br \\ Delly Oliveira Filho ${ }^{3}$ \\ Universidade Federal de Viçosa, Viçosa, MG, Brasil, delly@ufv.br
}

\begin{abstract}
In semi-transparent photovoltaic (STPV) systems, the heat accumulated in the back of the panels can be transmitted to the thermal zone and contribute to the heating effects. It can even cause an increase in the temperature of the photovoltaic (PV) cell, which reduces the efficiency of the system. This article aims to develop, through EnergyPlus software, a modeling method of the thermal properties of an STPV system, to evaluate the influence of the heat generated by the PV system in the internal temperature of the simulated environment and in the efficiency of the PV system itself. The method included computational simulations, in which we proposed STPV systems combined with different window configurations: single and double glazing, different thicknesses for the air gap, and high-performance glass. Shading devices play the role of the PV material to retrieve its thermal properties. The simulations showed that the STPV materials influence the thermal conditions of the zone, due to the increase in the mean air temperature $\left(3.3^{\circ} \mathrm{C}\right)$ and the increase in the surface temperature of the windows $\left(17.4^{\circ} \mathrm{C}\right)$. The differences among the window models were more significant in the thermal issues than in the variations of the PV system efficiency. The results confirm that the most used case in the literature presented the best performance, what strengthens the reliability of the proposed method.
\end{abstract}

Keywords: Solar Energy. Computational Simulation. Thermal Performance. EnergyPlus.

\section{Resumo}

Em sistemas fotovoltaicos semitransparentes (STPV), o calor acumulado na parte posterior dos painéis pode ser transmitido para a zona térmica, e contribuir para o aquecimento do ambiente. Ele pode ainda provocar o aumento da temperatura da célula fotovoltaica $(F V)$, o que reduz a eficiência do sistema. Este artigo tem como objetivo desenvolver, por meio do software EnergyPlus, um novo método de modelagem das propriedades térmicas de um STPV, ao avaliar a influência do calor gerado pelo sistema FV na temperatura interna do ambiente simulado e na eficiência do próprio sistema. O método incluiu simulações computacionais, em que foram propostos STPV integrados a diferentes configurações de esquadrias: vidros simples e duplos; espessuras diferentes para a camada de ar e vidros com propriedades térmicas especiais. Dispositivos de sombreamento desempenham o papel do material fotovoltaico para representar suas propriedades térmicas. As simulações mostraram que os STPV influenciam as condições térmicas da zona, tanto pelo acréscimo na temperatura média $\left(3,3^{\circ} \mathrm{C}\right)$, quanto pelo aumento da temperatura superficial das janelas $\left(17,4^{\circ} \mathrm{C}\right)$. As diferenças nos modelos de esquadrias foram mais significativas nas questões térmicas do que nas variações de eficiência do FV, com confirmação do caso mais usado na literatura como caso de melhor desempenho, o que reforça a confiança no método proposto.

Palavras-chave: Energia Solar. Simulação Computacional. Desempenho Térmico. EnergyPlus.

How to cite this article:

RODRIGUES, Thiago Toledo Viana; CARLO, Joyce Correna; OLIVEIRA FILHO, Delly. Thermal modeling of semi-transparent photovoltaics: impacts on the cell efficiency and on the zone performance. PARC Pesquisa em Arquitetura e Construção, Campinas, SP, v. 9, n. 4, dez. 2018. ISSN 1980-6809. Available at: <https://periodicos.sbu.unicamp.br/ojs/index.php/parc/article/view/8652785>. Date accessed: 02 nov. 2018. DOI:https://doi.org/10.20396/parc.v9i4.8652785. 


\section{Introduction}

Computational simulation is a great method for the quantification of the performance of buildings as it integrates several numerical models in a transient regime that aid the design, even before its construction or remodeling. However, softwares are still limited in modeling certain parameters, since they are a simplification of reality, such as the simulation of building-integrated photovoltaics (BIPV) using EnergyPlus. The identification of such limitations and their correction reduce the degree of uncertainty of the obtained data. Peng and Yang (2016) have shown that the PV module models used in EnergyPlus cannot simulate the thermal interactions between the BIPV systems and the environment with the required accuracy.

The BIPV systems can be part of the facade or roof of a building; thus, the thermal and fluid performance of the system is intrinsically linked to the building envelope (VUONG; KAMEL; FUNG, 2015). When the interaction between the BIPV system and the interior room occurs directly, which is more common in solar thermophotovoltaic (STPV) systems, the heat accumulated in the back of the panels can be dissipated by convection or by radiation to the internal zone, contributing to the heating of the room (WONG et al., 2008).

EnergyPlus provides PV models for simulation; however, its analysis is more focused on predicting the generation of electricity. The thermal aspects of the simulation still ignore some issues related to the mechanisms of heat transfer' between the component materials of a PV panel and the exterior and interior rooms, which can influence the thermal comfort and the energy performance of simulated buildings (RODRIGUES; CARLO, 2017).

The PV cell is an electrical device that converts solar radiation into electricity. However, in commercial systems, only 5 to $25 \%$ of the incident solar radiation is converted into electrical energy, and the rest is reflected or absorbed as heat (TIWARI; MISHRA; SOLANKI, 2011). Some of this heat is transferred back to the exterior air, while the remaining heat raises the temperature of the PV module (KANT et al., 2016). The high temperature decreases the efficiency of the energy conversion of the PV module (KANT et al., 2016).

Suwapaet and Boonla (2014) confirmed the impact of high operating temperatures of the PV module on its output power. The experiment carried out in Kamrieng, Maha Sarakham Province, Thailand, found operating temperature of $\mathrm{PV}$ modules from $46^{\circ} \mathrm{C}$ to $57^{\circ} \mathrm{C}$, which means an increase from 84 to $128 \%$ compared to the standard test conditions $\left(25^{\circ} \mathrm{C}\right.$ for the temperature of the module). With the increase in temperature, the monocrystalline silicon module generated $23 \%$ to $33 \%$ less output power, while the amorphous silicon module reduced $3 \%$ and $20 \%$. Thus, the amorphous silicon technology was indicated as more suitable for a tropical country such as Brazil, which presents high temperatures, especially during summer.

Rodrigues and Carlo (2017) tested the different PV modeling options within EnergyPlus, such as EOD (Equivalent One Diode) and SANDIA. Both consider the same coefficients related to the system efficiency, as the losses due to the temperature increase. The difference between them is that while the SANDIA calculation model has a database with several PV models previously measured by the Sandia Laboratory, the EOD model enables the insertion of these properties as input data in the software. Then, EOD enables the use of any other PV panel, as long as its electrical characteristics are known.

Furthermore, three methods for calculating the operating temperature of the PV cell were tested, including the ISOF (Integrated Surface Outside Face) method. EnergyPlus ISOF allows the use of the external surface temperature of the building component, where the PV system is located, as the operating temperature of the solar cell itself, describing the thermal influence of the building on the temperature of the system. However, the thermal properties of the materials assembled in a PV module are not the same as the materials commonly used in a building; thus, unrealistic operating temperatures of the cell will be used if the actual module components are not specified (RODRIGUES; CARLO, 2017).

Also, the software does not consider the PV system as a set of materials of the built environment and ignores the influence of the variation of the cell's operating temperature on the thermal calculations of the simulated zone (RODRIGUES; CARLO, 2017). This may overestimate or underestimate the heating or cooling consumption load, as well as influence the calculation of electricity generation, as it does not represent the actual condition and provides inaccurate temperature data, in addition to ignoring a number of mechanisms of thermal transmission between the panel and the environment or interior zone (WONG et al., 2005).

Some papers have explored a response to this software limitation. Didoné and Wagner (2013) have performed the thermal simulation of an office environment and obtained its energy consumption using EnergyPlus, while the PV generation was calculated separately because the software does not allow the direct modeling of a semi-transparent PV window. They needed to calculate the heat transfer to determine the temperature of the PV cell, as the program does not estimate the temperatures inside a window. 
Vuong, Kamel, and Fung (2015) have developed and implemented a BIPV model (called BIPVTSYSTEM) within the EnergyPlus source code. This model was based on the same equations of additional software, TRNSYS Type 567, but with some modifications regarding the thermal and fluid interactions. The BIPVTSYSTEM uses the EnergyPlus Sandia electrical model, and it calculates the temperature of the PV cell. Then, the Sandia model uses this temperature to calculate the voltage and current of the PV module and, consequently, the efficiency of the solar cell which is forwarded to EnergyPlus to perform the electricity generation calculations (VUONG; KAMEL; FUNG, 2015).

Wong et al. (2008) have used a similar method in their research. The authors, using field measurements on a prototype, have collected data on electricity generation and thermal and optical characteristics of STPV modules. The data collected, after being validated by calculation models, were incorporated into EnergyPlus as energy generation models, both electric and thermal, to evaluate the effect of semi-transparent PV material on the total energy consumption of a residential building located in Osaka, Japan (WONG et al., 2008). As expected, STPV panels increased the heat gained during the day, which may help reducing heating loads in winter, considering Osaka`s climate. However, this can increase up to three to five times the demand for cooling during summer (WONG et al., 2008).

In previous research, Wong et al. (2005) have used the same simulation method; however, the objective was to evaluate the effect of different STPV materials on the overall energy consumption of the building. Three types of STPV technology were simulated: polycrystalline silicon in single glazing, polycrystalline silicon in double glazing, and amorphous silicon in single glazing. The authors have confirmed the insulation properties of the double glazing window by identifying its low heat transfer coefficient, which is nearly half the value of the single glazing panel (WONG et al., 2005).

Although several studies focus on photovoltaic electricity generation, few studies that characterize the thermal performance of STPV panels were found. Therefore, there is a need to develop research studies that aim to investigate the thermal relationship between STPV systems and the building. Also, the research field requires more investigation of simulation tools capable of modeling the thermal performance of STPV systems concomitant to the electricity generation.

As no other work simulated the thermal properties of a PV module as a shading device, this is one of the relevancies of the present study. In EnergyPlus, until the present moment, the thermal contribution of the PV models was not considered in the simulations (PENG; YANG, 2016; RODRIGUES; CARLO, 2017).

\section{Review of EnergyPlus resources: shading devices}

The shading devices of EnergyPlus vary according to their geometry. Their properties, such as transmittance and absorptance, may be specified according to the type of material assembled to the solar protection. The type of configuration changes the transmittance of the window+shading system and the glass absorption of shortwave and longwave radiation (ENERGYPLUS, 2016a). The influence exerted depends on the position of the shading device in relation to the glass layer (inside, outside, or between layers), its transmittance, the amount of reflection between layers, and also the amount of radiation absorbed by it (ENERGYPLUS, 2016a).

The window+shading system presents the following properties: the transmittance of the system, the effective absorption of the glass, and the absorption of the shading device itself. The thermal properties of the system are given regarding the properties of the isolated device (which means, properties of the shading device in the absence of glass) and the properties of the isolated glass layer (ENERGYPLUS, 2016a).

The thermal model of the shading devices describes the thermal interactions between the shading layer and: the adjacent glasses, for all cases; the interior zone, for interior shading; the exterior environment, for exterior shading; and the gas, for shading in the gap of a double glazed window (ENERGYPLUS, 2016a).

Another characteristic of the thermal model of the shading device is the calculation of the airflow by natural convection between the shading device and the glazing. Buoyancy affects the temperature of the shading device and the glazing and, consequently, it is a major factor in the convective heat gained by the air zone from the shading layer and the glazing, in cases of interior shading (ENERGYPLUS, 2016a). The airflow model is based on ISO Standard 15099, "Thermal Performance of Windows, Doors, and Shading Devices - Detailed Calculations" (ISO, 2003).

EnergyPlus provides four categories of shading devices: shades, blinds, screens, and switchable glazing. For the category of interest in this work, that is the shade, we assume that it covers the entire glazed part of the window, including dividers and excluding the frames. Also, the program considers that the plane of the shading is parallel to the glazing (ENERGYPLUS, 2016b). The other categories do not fall within the scope of this study and will not be discussed. 
EnergyPlus establishes some rules for modeling multilayered windows (glass layers with or without shading devices). Regarding the shade category, the rules are:

- the first and last layers must be of solid material;

- an unique layer of gas must separate the adjacent glass layers;

- adjacent layers must not be of the same type;

- only a single shading is allowed;

- an exterior shade should be the first layer;

- an interior shade should be the last layer;

- for an interior or exterior shade, no gas layer should exist between them and the adjacent glass layer;

- the same type of gas with the same thickness must separate the between-glass shade from the adjacent glass layers;

- for triple glazed windows, the shade must be between the two inner glass layers;

- the shortest distance allowed ${ }^{2}$ between the glazing and the shade is $1 \mathrm{~mm}$.

The EnergyPlus manual instructions led to the selection of the window material shade model described above to estimate the thermal properties of STPV systems.

\section{Method}

This is an applied research, with an exploratory approach regarding the different stages of procedures. Simulations were run using EnergyPlus 8.4 with FullInteriorAndExterior solar distribution calculation method, and a weather file of the city of São Paulo, Brazil (RORIZ, 2012). São Paulo city presents two different seasons, summer and winter solely, as a consequence of its latitude and altitude, mainly. Thus, the PV system was analyzed in two days, one in summer and one in winter, while zone heat gains were analyzed for the year.

Choosing a day to carry out the analysis by the highest temperatures could lead to one close to the summer solstice. However, the radiation incidence on the North façade, where the STPV system is located, would be low, due to the high solar altitude during the solstice.

Therefore, the PV analyses were carried out for March $20^{\text {th }}$, and June $17^{\text {th }}$. The first one is close to the autumn equinox, and is characterized by having a high outside air temperature combined with solar radiation incidence on the north façade, where the semi-transparent PV system is located. The daily mean air temperature in March is $21.7^{\circ} \mathrm{C}$ and the solar altitude angle was $65^{\circ}$ at 12 p.m. on March $20^{\text {th }}$, while the maximum hourly temperature was $29.6^{\circ} \mathrm{C}$ at 03:00 p.m. On the other hand, June $17^{\text {th }}$ is close to the winter solstice and it was selected as a significant day to develop the analysis, due to its external low temperatures. The daily mean air temperature in June is $16.8^{\circ} \mathrm{C}$ and the solar altitude angle is $42^{\circ}$ at 12 p.m. on North façade, while the maximum hourly temperature is $18.8^{\circ} \mathrm{C}$ at 04:00 p.m.

No internal loads for occupation, equipment, and lighting were included, so that the temperature variation could be more sensitive to the heat transfer of the STPV systems, without the interference of other sources. This type of frame system with integrated semi-transparent PV material does not allow natural ventilation as it is not operable. Thus, the models exclude any natural ventilation input.

The electricity model of the PV module was always specified at the exterior glazing of the North-facing window. We chose the EOD (Equivalent One-Diode) model to calculate electricity generation and the ISOF (Integrated Surface Outside Face) method to estimate the temperature of the PV cell, according to Rodrigues and Carlo (2017). One of the main characteristics of ISOF is that the surface temperature is assumed as the operating temperature of the PV cell; therefore, the exterior glazing material had a strong influence on the efficiency of the PV system.

We obtained the electrical properties of the PV system using the PVSYST software (PVSYST, 2017), a tool that allows the analysis of different sets of PV systems to identify the best solution among hundreds of cataloged technical properties. The chosen model was the ASI THRU-1-IO 10\%, a semi-transparent amorphous silicon PV module, with an efficiency of $5.04 \%$ for standard test conditions (STC).

The thermal properties used as input data to model the shading devices system were obtained from Didoné and Wagner (2013).

As the SANDIA model does not present the chosen module in its database, the electrical properties and the coefficients that influence in its efficiency were withdrawn from PVsvst and inserted as input data on the EOD model.

\section{Base case}

For the base case, we modeled one thermal zone, $3 \mathrm{~m}^{2} \times 3$ $\mathrm{m}$ high, so that each linear meter of the façade would correspond to $1 \mathrm{~m}^{2}$ of the zone (Figure 1). Then, the compact floor area produced a model sensitive to the zone air temperature fluctuations. The façade is exposed to the sun and wind.

The simulated zone consists on a test prototype to evaluate if the proposed method is sensitive to the thermal influence of the STPV system on the environment, so it is smaller than a regular room's size. 
Despite the reduced area, the analysis is carried out by comparison. All the simulated cases have equal dimensions, which isolates the STPV system thermal properties effects from other interactions.

At the north wall, we modeled a glazed window with the dimensions of $1.30 \mathrm{~m} \times 2.80 \mathrm{~m}$, where we specified the electricity model of the STPV system. The other envelope materials follow the properties shown in Table 1 (ABNT, 2005).

The base case consists of a window with a single glass layer of $6 \mathrm{~mm}$ (Figure 2), called ' $6 \mathrm{~mm}$ Clear BC' (Table 2 ). The solar transmittance of the STPV system is lower than a single clear glass (6 mm Clear); thus we decided to use, for the base case, a glass with the same solar transmittance as the STPV material (6 mm Clear BC), to approximate heat gains from beam radiation with STPV cases.

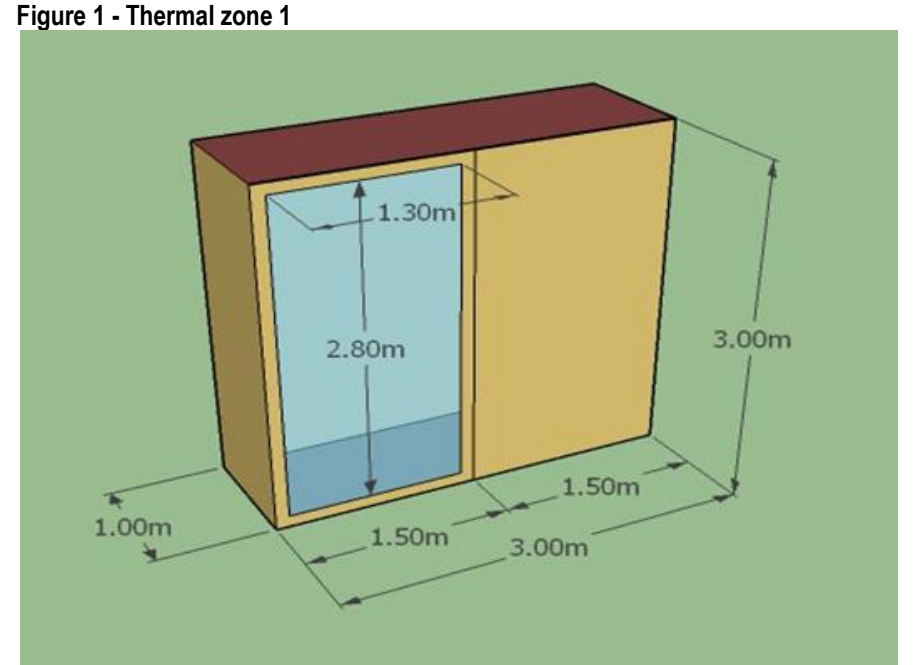

Source: The authors.

\begin{tabular}{|c|c|c|c|c|c|}
\hline Components & Materials & $\begin{array}{c}\text { Thickness } \\
(\mathrm{cm})\end{array}$ & Thermal transmittance $\left[\mathrm{W} /\left(\mathrm{m}^{2} \mathrm{~K}\right)\right]$ & $\begin{array}{c}\text { Thermal capacity } \\
{\left[\mathrm{kJ} / \mathrm{m}^{2} \mathrm{~K}\right]}\end{array}$ & $\begin{array}{c}\begin{array}{c}\text { Solar } \\
\text { absorption }\end{array} \\
\end{array}$ \\
\hline \multirow{3}{*}{ Walls } & Internal and external mortar & 2.0 (each) & \multirow{3}{*}{2.46} & \multirow{3}{*}{150} & \multirow{3}{*}{0.3} \\
\hline & Brick & 9.0 & & & \\
\hline & External paint (light color) & - & & & \\
\hline \multirow[b]{2}{*}{ Roof } & Asbestos cement & 0.7 & \multirow[b]{2}{*}{2.06} & \multirow[b]{2}{*}{233} & \multirow[b]{2}{*}{0.7} \\
\hline & $\begin{array}{c}\text { Air layer } \\
\text { Concrete slab }\end{array}$ & $\begin{array}{l}>5.0 \\
10.0\end{array}$ & & & \\
\hline
\end{tabular}

Source: Based on ABNT (2005).

Table 2 - Thermal properties of the glass and the STPV system used in the simulations

\begin{tabular}{ccccccc}
\hline Thermal properties & $6 \mathrm{~mm}$ Clear BC & $6 \mathrm{~mm}$ Clear & $3 \mathrm{~mm}$ Clear & 5mm Low-Iron & 3mm Low-E & 2mm A-SI Thru PV \\
\hline Solar Transmittance & 0.08 & 0.775 & 0.837 & 0.899 & 0.630 & 0.080 \\
\hline Solar Reflectance & 0.766 & 0.071 & 0.075 & 0.079 & 0.190 & 0.125 \\
\hline Solar Absorption & 0.154 & 0.154 & 0.088 & 0.022 & 0.180 & 0.795 \\
\hline Emissivity on front & 0.840 & 0.840 & 0.840 & 0.840 & 0.840 & 0.900 \\
\hline Emissivity on back & 0.840 & 0.840 & 0.840 & 0.840 & 0.100 & 0.900 \\
\hline Thermal conductivity (W/m.K) & 0.900 & 0.900 & 0.900 & 0.900 & 0.900 & 0.190 \\
\hline
\end{tabular}

Source: Based on Didoné and Wagner (2013) and EnergyPlus (2016-b).

Figure 2 - Base case

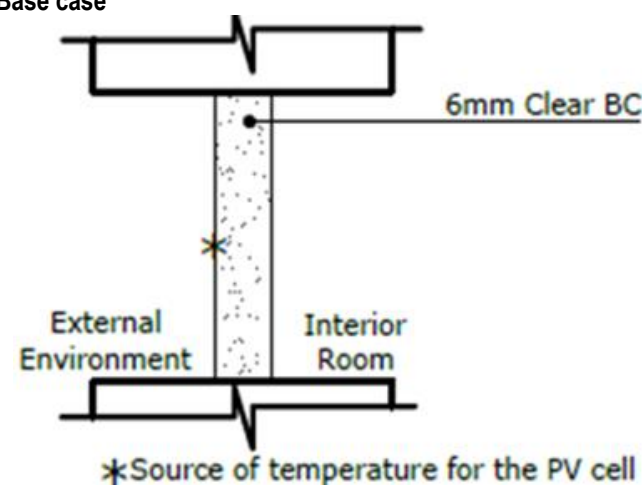

Source: The authors.

\section{Thermal models}

The thermal properties of the STPV systems and the heat transfer mechanisms between the PV material and the building were represented by the shading devices (shade category).

The thermal properties of the PV material were based on Jones and Underwood (2001), Elsayed (2016), Wong et al. (2005), Wong et al. (2008), and Didoné and Wagner (2013). The thermal properties of the STPV material for the shading device were based on Didoné and Wagner (2013), called A-SI Thru PV, which corresponds to the model of ASI THRU-1- 10\%. It consists of amorphous silicon solar cells with a transmittance of $8 \%$ and thickness of $2 \mathrm{~mm}$ (Table 2). 
Six window configurations with integrated STPV systems were proposed based on the rules established by EnergyPlus to model double or triple pane windows, previously presented. The shading devices comprise the thermal properties of the STPV material. The following items present the modeled cases.

The cases closest to the reality are cases 4 and 5 . Case 5 was based on Didoné and Wagner (2013) and represents the most usual STPV system, which adopts double glazing windows with thin PV film adhered to the inner face of the outermost glass (Figure 3).

Figure 3 - Layers of a window with STPV

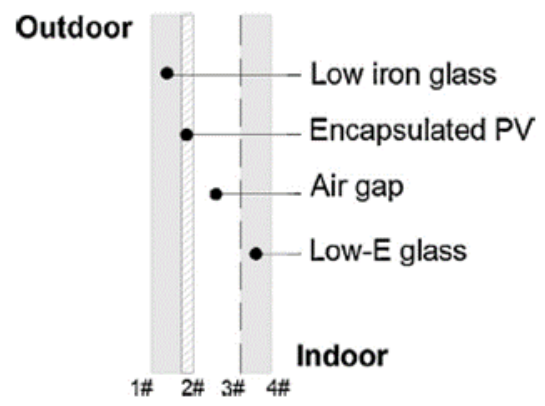

Source: Didoné e Wagner (2013).

Case 4 was proposed as a variation of case 5 in order to evaluate if low iron + low-E glazing adopted by Didoné and Wagner (2013) assists in the conversion efficiency of the PV cell and in the zone heat loads. Thus, low iron and low-E glasses are replaced for clear glass in case 4 .

Case 1 was simulated in order to compare the results of a single glazing window with the base case.

Cases 2 and 3 are theoretical models to be evaluated, as no real system was found without an air layer (case 2), or in which the PV film does not adhere to the glass layer (case $3)$. However, these two cases would help to identify the influence of the mentioned air layer distances on the PV system efficiency and the heat loads of the zone.

\section{Case 1 - Single glazing}

Case 1 consists of a single glass layer ( $6 \mathrm{~mm}$ Clear) and a shade facing the interior zone air ( $2 \mathrm{~mm} \mathrm{A-SI} \mathrm{Thru} \mathrm{PV),}$ with $1 \mathrm{~mm}$ between the glass and the shading device ${ }^{3}$ (Figure 4).

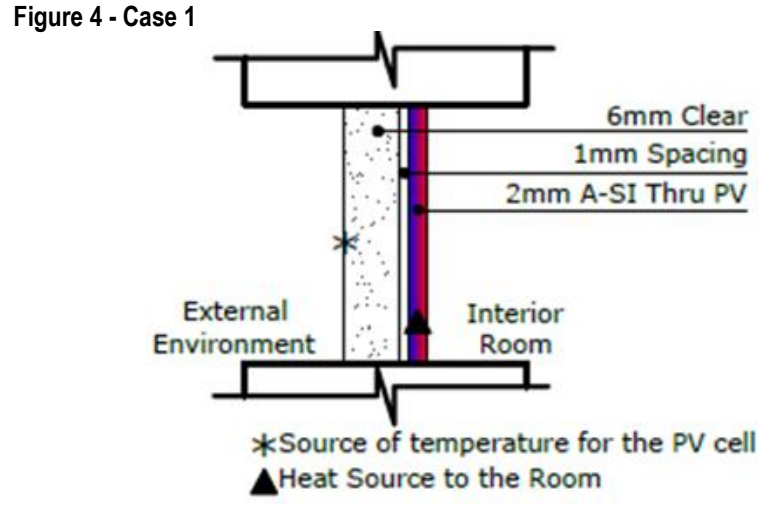

Source: The authors

\section{Case 2 - $1 \mathrm{~mm}$ air gap double glazing}

Case 2 consists of an exterior glass layer (6 $\mathrm{mm}$ Clear), a between glass shade ( $2 \mathrm{~mm}$ A-SI Thru PV) and an interior glass layer ( $3 \mathrm{~mm}$ Clear) in contact with the zone air. The shade is separated from the glass by two air layers of $1 \mathrm{~mm}$ each (Figure 5).

Figure 5 - Case 2

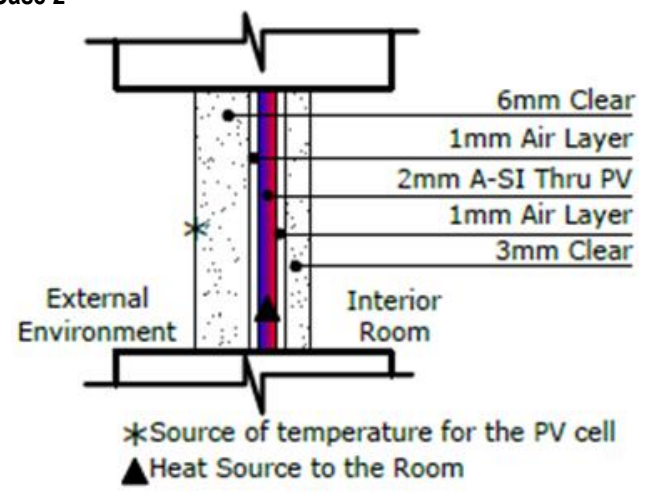

Source: The authors

\section{Case 3 - $6 \mathrm{~mm}$ air gap double glazing}

Case 3 consists of an exterior glass layer ( $6 \mathrm{~mm}$ Clear), a between glass shade ( $2 \mathrm{~mm}$ A-SI Thru PV) and an interior glass layer in contact with the zone air ( $3 \mathrm{~mm}$ Clear). The shade is separated from the glass by two air layers of $6 \mathrm{~mm}$ each (Figure 6).

Figure 6 - Case 3

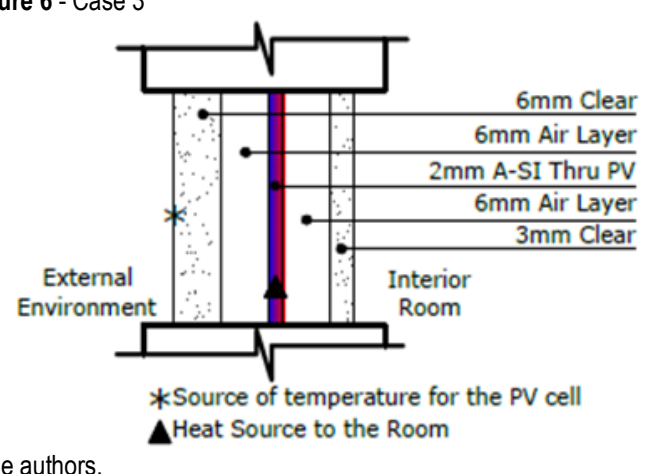

Source: The authors. 


\section{Case $4-1 \mathrm{~mm}$ and $12 \mathrm{~mm}$ air gap double glazing}

Case 4 is a streamline ${ }^{4}$ of the most common arrangement of layers for an integrated STPV system on a window that is available in the market. This case consists of an exterior glass layer (6 $\mathrm{mm}$ Clear), a between glass shade ( $2 \mathrm{~mm} \mathrm{A-}$ SI Thru PV) and an interior glass layer in contact with the zone air ( $3 \mathrm{~mm}$ Clear). The shade is $1 \mathrm{~mm}$ from the exterior glass layer and $12 \mathrm{~mm}$ from the interior (Figure 7). In case 4 , the window was modeled as a thermal zone.

Figure 7 - Case 4

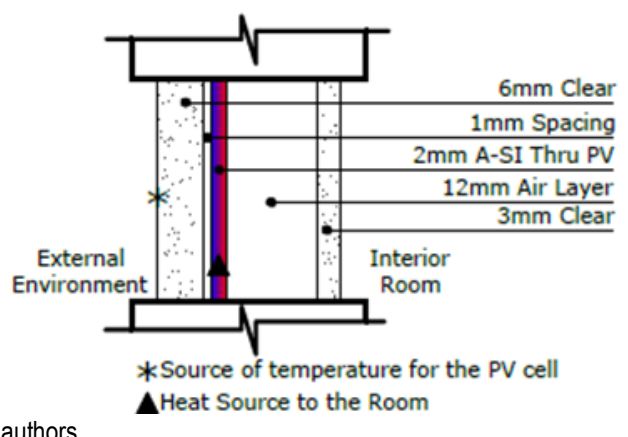

Source: The authors.

\section{Case $5-1 \mathrm{~mm}$ and $12 \mathrm{~mm}$ low-iron and low-E air gap double glazing}

Case 5 is a version of case 4, based on Didoné and Wagner (2013), who have used high-performance (extra-clear) glass in the glazing system, though the glass layers have different thicknesses in this study. Thus, this case consists of an exterior glass layer ( $5 \mathrm{~mm}$ Low Iron), a between glass shade ( $2 \mathrm{~mm}$ A-SI Thru PV), and an interior glass layer in contact with the zone air ( $3 \mathrm{~mm}$ Low-E). The shade is $1 \mathrm{~mm}$ from the exterior glass layer and $12 \mathrm{~mm}$ from the interior glass layer (Figure 8). As the previous case, the window was also modeled as a thermal zone. This extra clear glass is highly transmissive on the wavelength range of 300 to $2,500 \mathrm{~nm}$, which includes the spectral response of the A-SI Thru PV, from 380 to $790 \mathrm{~nm}$, but also higher wavelengths. Thus, the present case was created considering the positive results found in the literature, although the low iron glass performance is wider than the A-SI Thru PV response (DIDONÉ; WAGNER, 2013).

\section{Case 4 and case 5: modeling the thermal zones}

Cases 4 and 5 required special modeling because EnergyPlus requires the same type of air layers adjacent to the shading device and with the same thickness as dividers between shades and glass layers. However, a model closer to reality would present a thicker air layer of $12 \mathrm{~mm}$ between the STPV material and the interior glass layer, in comparison to the external glass.

In order to model cases 4 and 5, two thermal zones were created, as shown in Figure 9. Zone 1 is the interior room, similar to the other cases, while zone 2 comprises the interior space of the window, composed by the window+shading system.

Figure 8 - Case 5

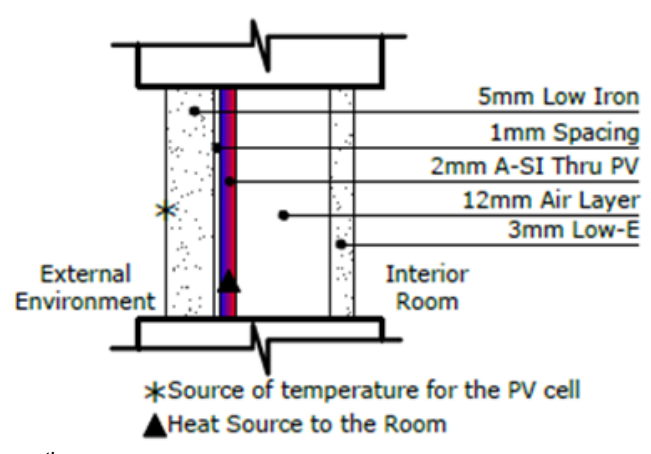

Source: The authors.

Zone 2 consists of an exterior north-facing glass layer, 1 $\mathrm{mm}$ air layer, a between glass shade, $12 \mathrm{~mm}$ air layer and an interior glass layer. In case 4 , the total window thickness is $24 \mathrm{~mm}$ (Figure 7), while it is $23 \mathrm{~mm}$ in case 5 (Figure 8). The $12 \mathrm{~mm}$ air layer separates the STPV, or shade layer, from the interior glass layer. As required in EnergyPlus modeling, the south-facing glazing of zone 2 is in contact with the north-facing glazing of zone 1, even though they are the same layer in a real window. Therefore, the software can estimate an air temperature in zone 2, which is the air temperature of the double glazing window.

Finally, the surfaces representing the north, east, and west walls, as well as the roof and floor of zone 2, are adiabatic, to avoid any heat transfer from the exterior environment to the window.

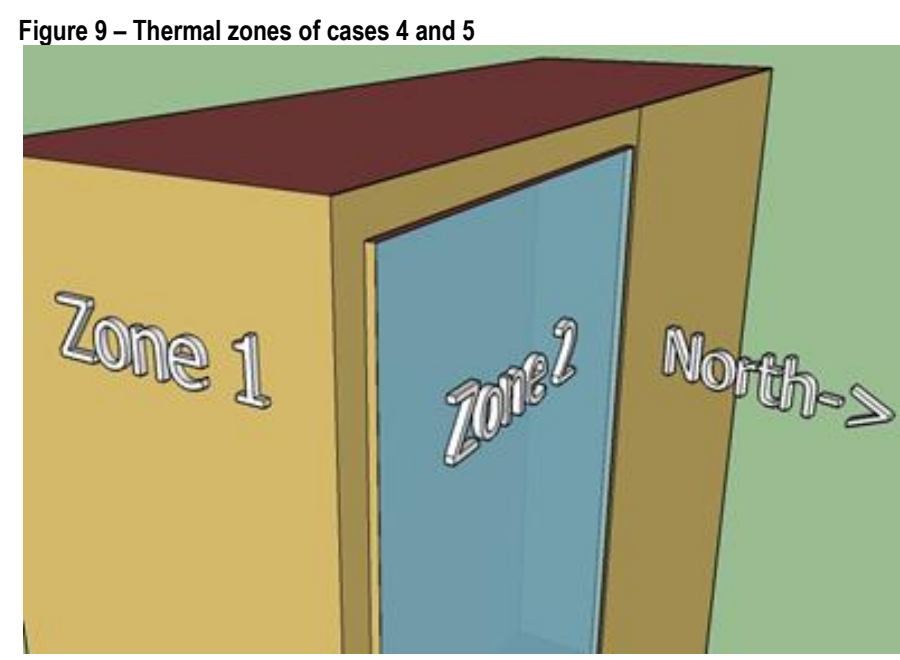

Source: The authors.

\section{Limitations of the method}

The electric model is positioned on the exterior surface of the glazing, and the surface temperature of the exterior 
glazing is the operating temperature of the PV cell, as the calculation method is the 'Integrated Surface Outside Face'. Although it does not illustrate the actual situation, EnergyPlus does not allow to configure an electric model in a shade, which is a limitation of this simulation.

Thus, convection and long-wave radiation transfers from the shading device will impact the heat balance of the exterior glazing, which superficial temperature will be closer to what the actual temperature of the PV cell would be. Although this method cannot estimate the actual operating temperature of the PV cell, it is more reliable than the simple inclusion of an electric model on a surface that does not consider the PV thermal properties, which is the base case.

\section{Results and discussions}

The results will be presented here only for March 20th, since the performance pattern did not differ from summer (March 20 ${ }^{\text {th }}$ ) to winter day (June $17^{\text {th }}$ ).

\section{Mean air temperature in zone 1}

Case 1 presented the highest temperatures during the daylight period, and the difference between it and the base case was approximately $3.3^{\circ} \mathrm{C}$ at 02:00 p.m. (Figure 10), considering this theoretical small thermal zone.

In case 1, the PV is in direct contact with the interior air of the zone as the window+shading system consists of single glazing and, consequently, a higher heat gain for zone 1 . In case 5, for example, the double glazing that composes the window and the interior low-E glass layer ensured that the heat gains would be lower than in case 1 .
Cases 2 and 3 differ by the thickness of the air layer, and they presented similar performance: their highest temperature difference was $0.3^{\circ} \mathrm{C}$ at 08:00 a.m.

During the morning until 01:00 p.m., case 4 presented the lowest temperatures; unlike after sunset, when it presented the highest. Case 5 temperatures were similar to case 4 , even though the single clear glass of the latter caused a temperature peak delay that the low iron + low-E of the former could not cause. Case 4 thermal delay point out the latter as a better system for thermal performance purposes, because the low iron glass is highly transmissive for longer wavelengths, being that the reason for the higher heat gain.

\section{Windows interior surface temperature}

Case 5 presented the highest surface temperature peak during the daylight period (approximately $47^{\circ} \mathrm{C}$ ), and the difference between it and the base case was approximately $17.4^{\circ} \mathrm{C}$, at 01:00 p.m. (Figure 11). At the same hour, case 4 presented the lowest differences compared to the base case, approximately $8.6^{\circ} \mathrm{C}$, but still significant to impact the radiant temperature under which the users are exposed.

The distance between the PV and the interior glass layer of case 4 accounts for the thermal zone lower temperatures, which case 5 could not reproduce due to its different glazing properties. The exterior glazing of case 5 is a high solar transmittance glass, which intensifies the heat gains of the between glass PV layer and, consequently, the emissions to the interior glass, since iron oxide blocks irradiance in the red-infrared portion of the spectrum. Therefore, the window on case 5 presented the highest interior surface temperatures, even though case 5 low-E glass could maintain the mean air temperatures close to case 4, as seen in Figure 10.

Figure 10 - Mean Air Temperature in Zone 1

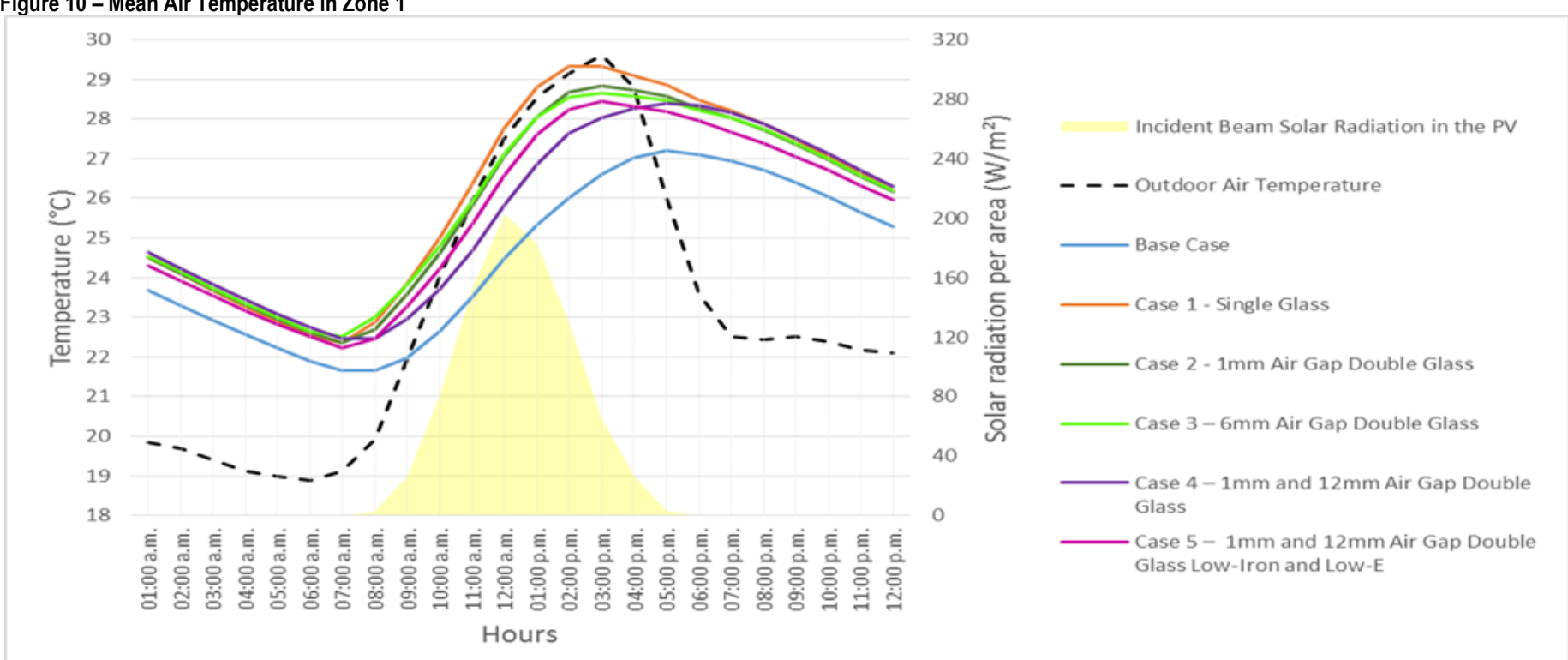




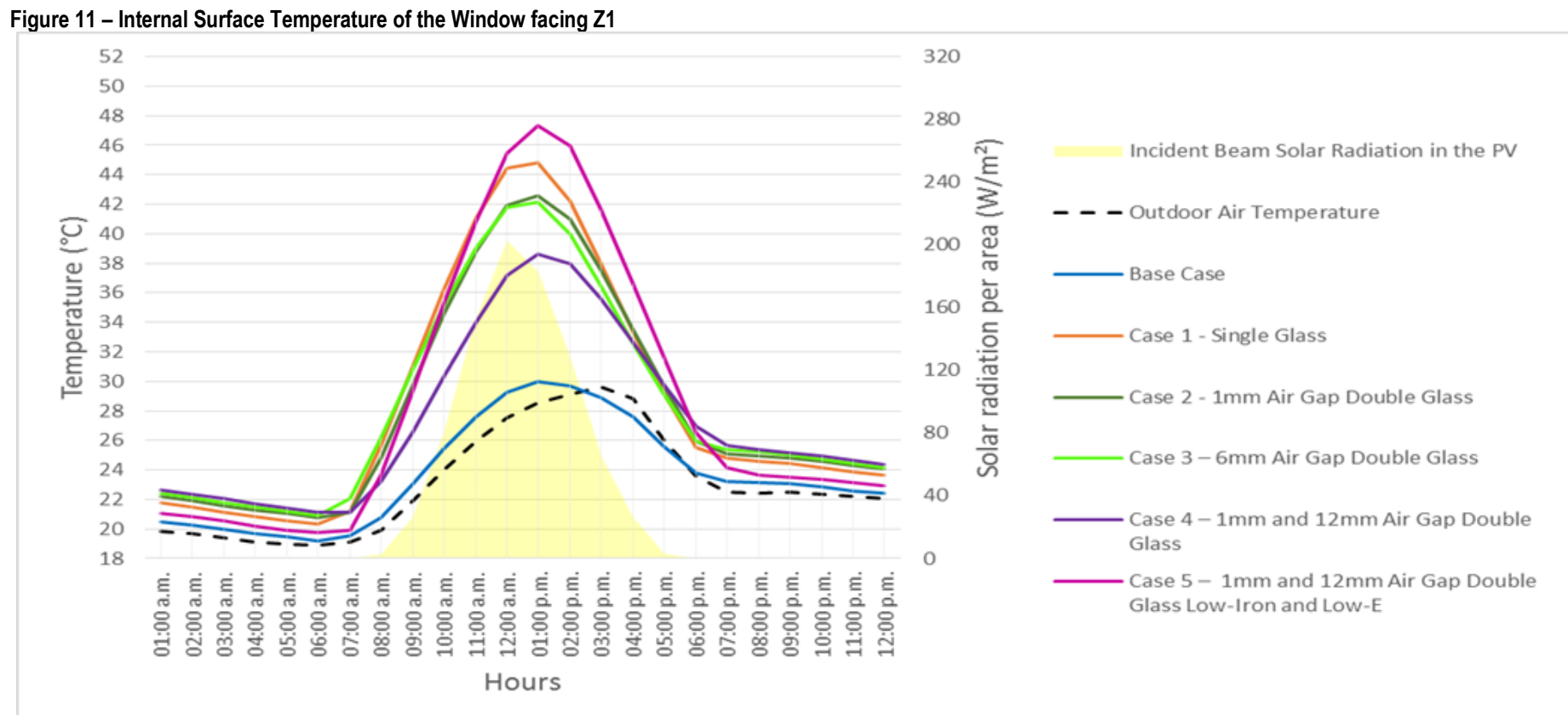

Source: The authors

Excluding the base case, the greatest difference during the insolation period was approximately $8.7^{\circ} \mathrm{C}(01: 00$ p.m. $)$, between case 4 and case 5 . Case 1 presented the second highest peak during the daylight period, approximately $44.8^{\circ} \mathrm{C}(01: 00$ p.m. $)$, as it contained a single glazing window. Thus, the surface measuring the temperature is the same that first receives beam radiation, unlike the double glazing windows, in which the second glass layer receives beam radiation after it is transmitted through the exterior glass layer and the shade. Finally, case 2 and case 3 presented small differences: approximately $1.4^{\circ} \mathrm{C}$ at 8:00 a.m., the hour of greatest variation Windows exterior surface temperature.

The simulations resulted in very significant differences on the exterior surface temperature of the window (Figure 12), which may impact the efficiency of the PV system, as it is used as the temperature of the PV cell itself. The difference reached approximately $20^{\circ} \mathrm{C}$ between the base case and case 5 . The exterior surface temperature peak was close to $30^{\circ} \mathrm{C}$ at 01:00 p.m. in the base case, while it reached almost $50^{\circ} \mathrm{C}$ in case 5 .

Figure 12 - External surface temperature of the window = temperature of the PV cel

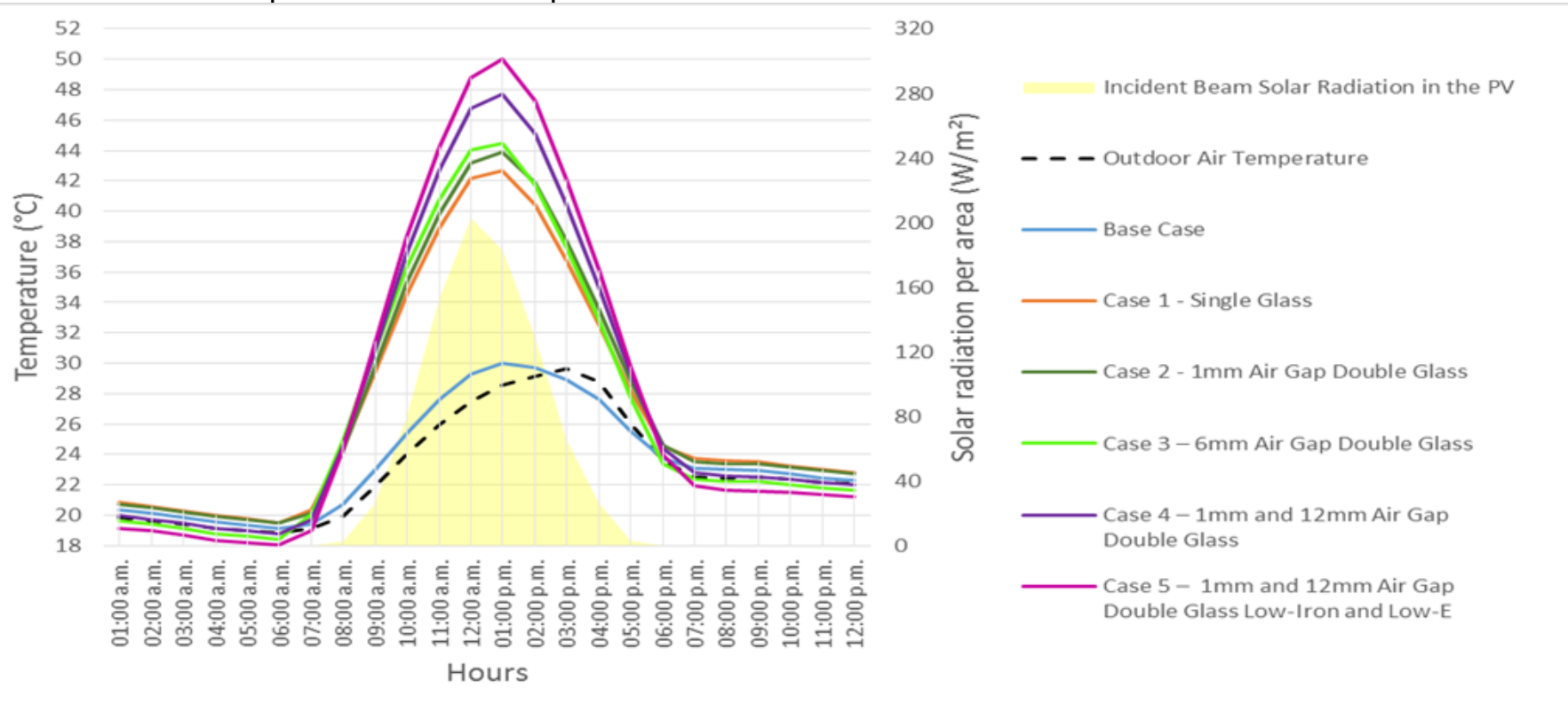

Source: The authors. 
Excluding the base case, which did not have the shade as a thermal model for the PV, the highest variation among the other cases was approximately $7.3^{\circ} \mathrm{C}$, between case 1 and case 5 (01:00 p.m.). Case 1 presented the lowest temperature during daylight hours because of the shade losses directly to the interior room. In the other cases, double glazing held some of the heat inside the window.

Case 2 and case 3 presented similar temperatures, which differences reached only $1^{\circ} \mathrm{C}$. It indicates that convective gains do not differ, as radiative gains do not depend on distance, but shape factor, and the models have the abovementioned limitation regarding conduction heat transfer.

\section{Efficiency of the PV system}

The efficiency of the system remained below that obtained in the standard test conditions ${ }^{5}$ (STC), as an expected result of changing the boundary conditions in a real operating situation. Also, we adopted an efficiency of $95 \%$ for the power inverter, according to a typical efficiency available in the market.

The efficiency obtained in the PVSYST database in the STC was $5.04 \%$ for the chosen model, while the maximum efficiency found in the simulations was $3.42 \%$ for the base case at 12:00 p.m. (Figure 13), 32.14\% less than the efficiency in the STC. The base case still does not account for the thermal properties of the PV material, which means that the system losses may be even higher as a function of the cell temperature. Also, the efficiency is even lower at other moments; according to the solar radiation and the outside temperature, it decreases to $0.4 \%$, as at 07:00 a.m.
We calculated the losses in the efficiency of the system comparing the base case and the other cases, which contain inputs of thermal properties of the PV system. At the system peak generation at 12:00 p.m., the greatest difference on the efficiency was between the base case, of $3.42 \%$, and case 5 , of $3.18 \%$. Considering the base case as the case with maximum efficiency, case 5 , in comparison, presented a decrease of $7 \%$. When base case is excluded, the efficiency differences were not significant (Figure 13). As previously pointed out, the low iron glass simulation raised some questions regarding the spectral response. All the cases were simulated assuming average wavelengths of the solar spectrum. High transmissive glazing like low iron should be handled with caution, since it requires specific modeling to link glass solar transmittance and reflectance to different wavelength ranges. Then, when case 5 presented the lowest efficiency ratios it was clear that the low iron glass was simulated with a higher transmittance in a wavelength range that is outside the spectral response of the PV device. Therefore, case 4 performance was better than case 5 , regarding both the efficiency of the system and the thermal performance of the room.

Winter conditions were also assessed, focusing on June $17^{\text {th }}$. However, the variation between the simulated cases was very similar to the results found for summer conditions. The expected differences were recognized between the two seasons, as summer had higher temperatures and winter lower temperatures; however, the differences between the simulated cases were similar.

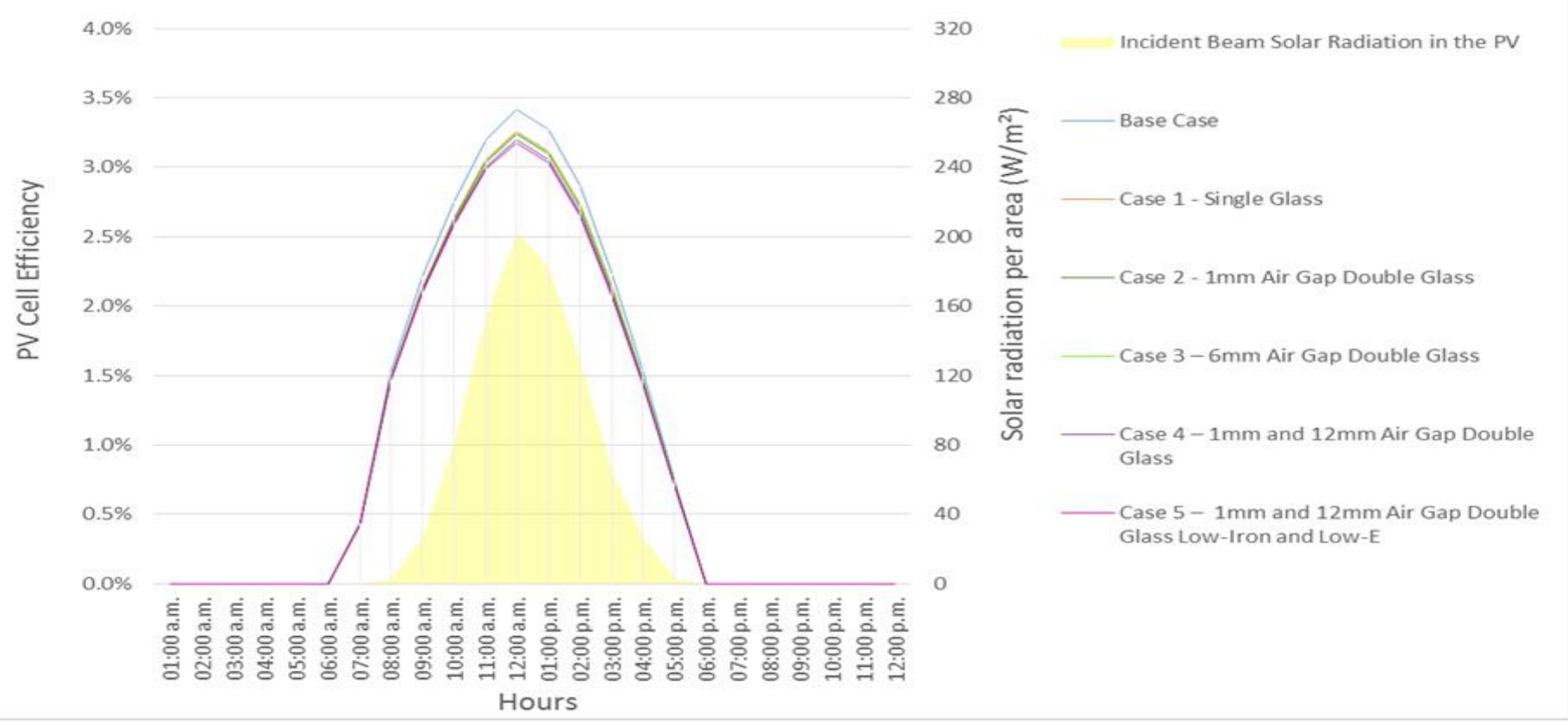


The efficiency of the system was slightly higher for the winter day, as the lower altitude of the sun provided a higher angle of incidence of beam solar radiation in the $\mathrm{PV}$, that is installed on a vertical surface. During the winter day, the incident maximum beam solar radiation on the PV was $248 \mathrm{~W} / \mathrm{m}^{2}$ at $12: 00$ p.m. and the efficiency was $3.6 \%$ in the base case; while at the same hour it was $202 \mathrm{~W} / \mathrm{m}^{2}$ and $3.4 \%$, on the summer/equinox day, March $20^{\text {th }}$.

Also, on the winter day, the temperature of the PV cell was lower, as the outside air temperature also remained lower, which contributed to a higher efficiency of the PV system. For the base case, on the winter day, the maximum temperature recorded for the cell was close to $19^{\circ} \mathrm{C}$ at 01:00 p.m. and the outside air temperature was $16^{\circ} \mathrm{C}$, while it was, respectively, $30^{\circ} \mathrm{C}$ and $28^{\circ} \mathrm{C}$, on the summer/equinox day. These differences resulted in a decrease of $5 \%$ on the peak efficiency for the summer/equinox day.

\section{Thermal effects in the zone}

Figure 14 presents the monthly average heat gains and losses in the zone through the windows for all the cases except case 2 , since its results are similar to case 3 . We can see that transmitted solar radiation is not the main contributor to heat gains, except in the base case, which is higher than the others, as it does not have an SPTV.

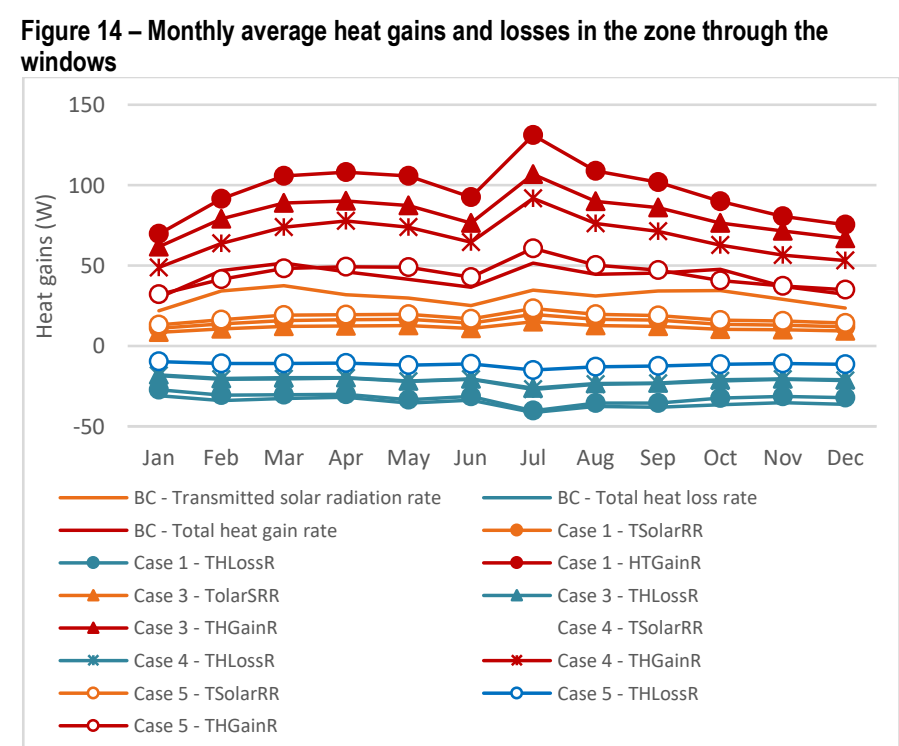

Source: The authors.

The heat losses through the window are similar between the single glazed cases - base case and case 1 , and between the double glazed cases with clear glass - case 3 and case 4. The lowest heat loss among the double glazed cases is credited to case 5, due to the low iron and low-E glasses.

However, the similarities between the base case and case 1 is restricted to this phenomenon, as the total heat gains are the highest in case 1, as it is single glazed with SPTV.
The double glazed window of cases 3 and 4 prevents higher heat gains due to its U-factor of $2.686 \mathrm{~W} / \mathrm{m}^{2} \mathrm{~K}$ in both cases. Then, the lower total heat gain through windows - represented by the base case - shows how the STPV can impact the total heat gains, if compared to case 1 , and how a double glazing window can reduce part of these gains. Nevertheless, case 5 total heat gains are similar to the base case - especially on summer, and slightly higher on winter - though it presents a lower Ufactor $\left(3.484 \mathrm{~W} / \mathrm{m}^{2} \mathrm{~K}\right)$ than base case $\left(5.778 \mathrm{~W} / \mathrm{m}^{2} \mathrm{~K}\right)$. The highest reduction between the monthly average heat gains of case 1 and the base case was of $80 \mathrm{~W}$ in July.

Figure 15 presents the hourly heat gains and losses for a complete year of all simulated cases, with maximums of $369 \mathrm{~W}$ for the base case, $797 \mathrm{~W}$ for case $1,621 \mathrm{~W}$ for case $2,621 \mathrm{~W}$ for case 3 and $570 \mathrm{~W}$ for case 4 and $383 \mathrm{~W}$ for case 5 .

Figure 15 - Hourly heat gains for a complete year

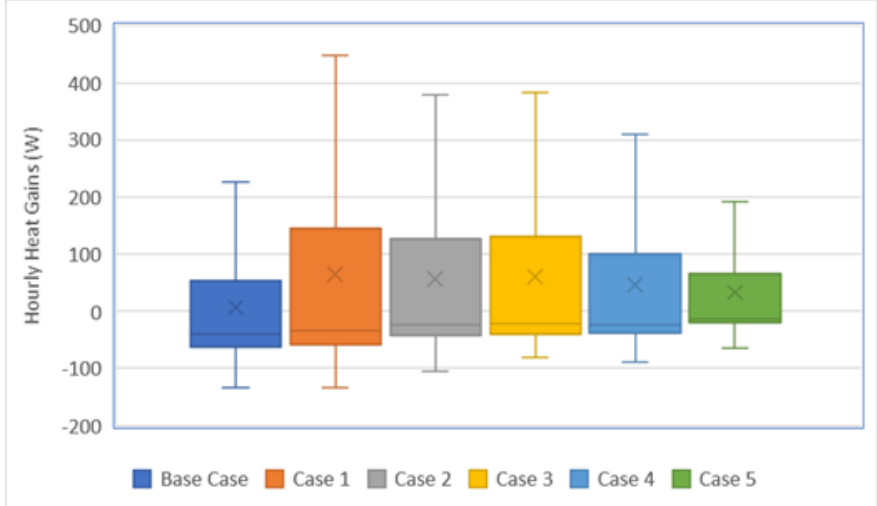

Source: The authors.

The results show how case 5 presents lower total heat gains than case 4 , but higher solar radiation transmission to the room. The solar radiation transmission explains the higher surface temperature found in case 5 internal glass, compared to case 4 (Figure 11), although case 5 mean air temperature peak is close to case 4 (Figure 10). Moreover, case 5 mean air temperatures are higher than base case temperatures due to the heat balance between gains and losses, as case 5 presented the lowest monthly losses, shown in Figure 14.

\section{Conclusions}

As expected, the study showed how PV material impacts the heat gains and, consequently, the performance of thermal zones and PV systems in simulations. The analyzed indicators were the mean air temperature of the thermal zone and the interior surface temperature of the windows. Their increase can impact the thermal comfort of users, or the HVAC energy consumption. The surface temperature can also impact the radiant temperature and, then, users' thermal comfort in all the studied cases. 
A great variation in the exterior surface temperature of the simulated cases was observed when compared to the base case. The temperature of the PV cell adopts the exterior surface temperature in EOD calculation model, and therefore, it was directly related to the efficiency of the system. The simulations showed that constant efficiencies obtained under standard test conditions for the PV system overestimates the energy generation, as there is a high variation in efficiency during the day in a real operating situation.

Regarding the windows performance through the year, the balance between heat gains and losses showed why case 5 is the most usual case in literature. Although it presented the highest window surface temperature and mean air temperatures close to case 4 , case 5 heat gain balance through the window to the zone is the lowest among all simulated cases. The result confirms why case 5 is one of the most used glazing system with STPV. Moreover, it points out the reliability of the proposed method using a shading device to account for heat gains in the zone.
Although variations in the efficiency of the thermal models seem to be less expressive when compared to the base case, the losses in percentage can be significant in a large-scale generation system as a PV material with low efficiency - as the semi-transparent amorphous silicon may cover large surface areas. It causes an increase in energy generation. Also, more efficient PV technologies than the semi-transparent amorphous silicon may present higher surface temperatures and, consequently, increase the efficiency losses..

Finally, it is important to highlight that the different simulated windows influenced more the thermal comfort variables than the variations of the efficiency of the PV system. Simulating high performance glass, as low iron, requires detailed input regarding the spectral response. The so-called extra-clear glass does not present modeling limitations for efficiency optimization of more traditional crystalline silicon PV technology, as it has a spectral response up to 1100-1200 nm, while the combination with amorphous silicon PV modules takes simulation to a more detailed input level.

\section{Acknowledgments}

The authors are grateful for the support of CAPES, FAPEMIG and CEMIG-D/ANEEL.

\section{Notes}

(1) The heat gained during the day with PV systems consists of absorbed solar radiation, convection and conduction exchanges, and the heat generated during the conversion of solar radiation into electric energy (WONG et al., 2008).

(2) This rule ends up preventing the STPV from being assembled directly on the exterior glazing (the most common situation in real cases), which is a limitation of this study as it does not describe the conduction heat transfer between the exterior glass and the STPV material.

(3) The $1 \mathrm{~mm}$ layers, are the minimum distance allowed between the glass and the shading device by EnergyPlus. In the device's input data it is requested this thickness, that is automatically recognized by the software as an air layer (ENERGYPLUS, 2016b).

(4) As shown in item 3.0, EnergyPlus requires a minimum spacing of $1 \mathrm{~mm}$ between the layer of glass and the shading device. However, the semi-transparent PV material is adhered to the back of the outermost layer of glass in real STPV systems. Therefore, this was the best approximation in terms of positioning obtained in the thermal models, although it continues to avoid the existing exchanges by conduction and a real case.

(5) Standard ASTM E-1036 (ASTM, 1985) defines the following values as standard test conditions (STC) to achieve the efficiency of a photovoltaic module: $1000 \mathrm{~W} / \mathrm{m}^{2}$ for irradiation, $25^{\circ} \mathrm{C}$ for the temperature of the module, AM 1.5 for solar spectrum, $20^{\circ} \mathrm{C}$ for external air temperature, and $1 \mathrm{~m} / \mathrm{s}$ for air velocity.

\section{References}

ABNT - ASSOCIAÇÃO BRASILEIRA DE NORMAS TÉCNICAS. NBR 15220-2: Desempenho térmico de edificações - Parte 2: Métodos de cálculo da transmitância térmica, da capacidade térmica, do atraso térmico e do fator solar de elementos e componentes de edificações. Rio de Janeiro, 2005.

ASTM - AMERICAN SOCIETY FOR TESTING AND MATERIALS. ASTM E-1036: Standard Methods of Testing Electrical Performance of Nonconcentrator Terrestrial Photovoltaic Modules and Arrays Using Reference Cells. USA, 1985. 
DIDONÉ, E. L.; WAGNER, A. Semi-transparent PV windows: A study for office buildings in Brazil. Energy and Buildings, v. 67, n. 3, p. 136-142, Dec. 2013. DOI:https://doi.org/10.1016/j.enbuild.2013.08.002

ELSAYED, M. S. Optimizing thermal performance of building-integrated photovoltaics for upgrading informal urbanization. Energy and Buildings, v. 116, p. 232-248, Jan. 2016. DOI:https://doi.org/10.1016/j.enbuild.2016.01.004

ENERGYPLUS. EnergyPlus Documentation. Version 8.4. U. S. Department of Energy, Jan. 2016. Available in: https://energyplus.net/. Accessed: Sep. 19, 2017.

ENERGYPLUS. Engineering Reference Manual. Versão 8.4. Ernest Orlando Lawrence Berkeley National Laboratory; 2016a.

ENERGYPLUS. Input Output Reference Manual. Versão 8.4. Ernest Orlando Lawrence Berkeley National Laboratory; 2016b.

ISO - International Standardization Organization. ISO 15099: 2003. Thermal performance of windows, doors, and shading devices - Detailed calculations. International Standards Organization, Nov. 2003.

JONES, A. D.; UNDERWOOD, C.P. A thermal model for photovoltaic systems. Solar Energy, v. 70, p. 349-359, 2001. DOI:https://doi.org/10.1016/S0038-092X(00)00149-3

KANT, K.; SHUKLA, A.; SHARMA, A.; BIWOLE, P. H. Thermal response of poly-crystalline silicon photovoltaic panels: Numerical simulation and experimental study. Solar Energy, v. 134, p. 147-155, Sep. 2016.

DOI:https://doi.org/10.1016/j.solener.2016.05.002

PENG, C.; YANG, J. The effect of photovoltaic panels on the rooftop temperature in the EnergyPlus simulation environment. International Journal of Photoenergy, v. 2016, Jan. 2016. DOI:https://doi.org/10.1155/2016/9020567

PVSYST. Pvsyst Software Photovoltaic. 2017. Available in: http://www.pvsyst.com/en/. Accessed: Aug. $15,2017$.

RODRIGUES, T. T.; CARLO, J. C. Simulação Térmica de Sistemas BIPV por meio do EnergyPlus. In: ENCONTRO NACIONAL DE CONFORTO NO AMBIENTE CONSTRUÍDO, 14. Camboriú, 2017. Anais... Camboriú: ANTAC, 2017. p. 808-817.

RORIZ, M. Correções nas Irradiâncias e Iluminâncias dos Arquivos EPW da Base Antac. 2012. Available in: http://www.labeee.ufsc.br/sites/default/files/arquivos_climaticos/correcao_epw_antac.pdf. Accessed: May 15, 2017.

SUWAPAET, N.; BOONLA, P. The Investigation of Produced Power Output During High Operating Temperature Occurrences of Monocrystalline and Amorphous Photovoltaic Modules. Energy Procedia, v. 52, p. 459-465, Jul. 2014.

DOI:https://doi.org/10.1016/j.egypro.2014.07.098

TIWARI, G. N.; MISHRA, R. K.; SOLANKI, S. C. Photovoltaic modules and their applications: A review on thermal modelling. Applied Energy, v. 88, p. 2287-2304, Feb. 2011. DOI:https://doi.org/10.1016/j.apenergy.2011.01.005

VUONG, E.; KAMEL, R. S.; FUNG, A. S. Modelling and Simulation of BIPV/T in EnergyPlus and TRNSYS. Energy Procedia, v. 78, p. 1883-1888, Nov. 2015. DOI:https://doi.org/10.1016/j.egypro.2015.11.354

WONG, W. P.; SHIMODA, Y.; NONAKA, M.; INOUE, M.; MIZUNO, M. Field Study and Modeling of Semi-transparent PV in Power, Thermal and Optical Aspects. Journal of Asian Architecture and Building Engineering, v. 4, p. 549-556, Nov. 2005.

WONG, W. P.; SHIMODA, Y.; NONAKA, M.; INOUE, M.; MIZUNO, M. Semi-transparent PV: Thermal performance, power generation, daylight modelling and energy saving potential in a residential application. Renewable Energy, v. 33, p. 1024-1036, May. 2008. DOI:https://doi.org/10.1016/j.renene.2007.06.016

\section{${ }^{1}$ Thiago Toledo Viana Rodrigues}

Arquiteto e Urbanista. Mestre em Arquitetura e Urbanismo. Professor contratado no Instituto Ensinar Brasil - João Monlevade. Endereço postal: Av. P. H. Rolfs, s/nº, Centro, Viçosa, Minas Gerais, Brasil, CEP 36570-900 


\section{${ }^{2}$ Joyce Correna Carlo}

Arquiteta e Urbanista. Doutora em Engenharia Civil. Professora Adjunta na Universidade Federal de Viçosa. Endereço postal: Av.

P. H. Rolfs, s/nº, Centro, Viçosa, Minas Gerais, Brasil, CEP 36570-900

\section{${ }^{3}$ Delly Oliveira Filho}

Engenheiro Eletricista. Doutor em Engenharia Elétrica. Professor Titular na Universidade Federal de Viçosa. Endereço postal: Av.

P. H. Rolfs, s/nº, Centro, Viçosa, Minas Gerais, Brasil, CEP 36570-900 